\title{
СІЛЬСЬКІ ТЕРИТОРІЇ ЯК ОБ'ЄКТ ДЕРЖАВНОЇ ПОЛІТИКИ У СФЕРІ ЖИТЛОВО-КОМУНАЛЬНОГО ГОСПОДАРСТВА
}

Бізонич Д. В., канд. тех. наук, директор ТОВ «Еталонтехсервіс» м. Харків, Україна.

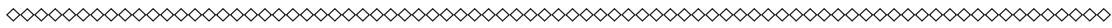

В статті розглянуто основні концепції типізації сільських територій, які є територіальною основою для організації місцевого самоврядування в нашій країні та управління сферою ЖКГ, яка в свою чергу, $\epsilon$ підсистемою інфраструктури адміністративнотериторіальних одиниць цьього рівня. Проблеми в управлінні сільськими територіями, їх відмінності, які слугують основою для типізації, позначаються на управлінні інфраструктурними об'єктами, в тому числі - житлово-комунальному господарстві. В статті визначені також основні нормативно-правові засади в регулюванні розвитку сільських територій, подальші напрями удосконалення державної політики в иій сфері. Досліджено зміст термінів «аграрний» $i$ «сільський», встановлено, щуо на основі різноманітних ознак та історичного розвитку поняття «сільський сектор» є значно ширшим, ніж «аграрний сектор». Встановлено взаємозв 'язки між розвитком сільських територій та регіональним розвитком.

Ключові слова: державна політика, житлово-комунального господарство, державне регулювання, село, селище, сільські території, просторове планування, муніципальне господарство.

Постановка проблеми у загальному вигляді. Житловокомунальна інфраструктура $€$ складовою інфраструктури населеного пункту і охоплює територіальну структуру. Одиницями 
територіальної організації влади та публічного управління $\epsilon$ країна, регіон, область, місто, сільський адміністративний район, населений пункт, тобто ведучи мову про сферу управління ЖКГ, базовим рівнем для його організації та функціонування виявляється найнижча ланка в цій територіальній системі: село, селище або місто.

В галузевому та територіальному аспектах підтримання необхідних пропорцій розвитку житлово-комунальної сфери є одним iз напрямів регіонального розвитку та децентралізації, оскільки ця сфера $є$ дуже проблемною в умовах розвитку ринкових відносин.

Що стосується сільських населених пунктів (сіл та селищ), то такі території в публічному управлінні посідають дуже важливе місце в контексті розвитку та реформування системи місцевого самоврядування. Вони слугують основним ресурсом для забезпечення місцевого самоврядування в нашій країні i розглядаються з різних державотворчих аспектів.

Для досягнення сільськими територіями якісно нового рівня розвитку необхідно подолати існуючий моноцентризм в розумінні ïx сутності, розглядати їх ресурсний потенціал та функції на основі територіального підходу. У цьому змісті сільські території розуміються як місце розвитку, простір виробничо-господарської, соціальної, духовно-культурної, політичної діяльності, природний ландшафт і життєве середовище. Згідно з територіальним підходом, об'єктом управління виступає цілісна система загалом, а не тільки iii окремі елементи. Це дає можливість досягати збалансованого розвитку, інтегрувати сільську і міську підсистеми суспільства, долати міжгалузеві, внутрішні та міжрегіональні диспропорції. Разом $з$ тим, територіальний підхід вимагає окремого дослідження щодо розбудови відповідної інфраструктури, в тому числі житловокомунального господарства, яка є дуже проблемною в управлінні на рівні найнижчих територіальних одиниць.

Аналіз останніх досліджень і публікацій. 3 огляду на предмет дослідження на особливу увагу заслуговують праці таких вчених 3 державного управління, як I. Баланюка, О. Батанова, О. Васильєва, I. Дегтярьової, В. Смельянова, В. Мамонової, 
О. Павлова, Н. Нижник, В. Яцуби та інших. Водночас, зважаючи на складну ситуацію розвитку сільськими територіями, їх соціальну та матеріальну деградацію, постає необхідність в дослідженні особливостей розвитку сільських територій як суб' єктів управління ЖКГ на цьому рівні територіальної організації влади.

Формулювання цілей статті (постановка завдання) дослідити особливості типізації сільських територій (села та селища) як адміністративно-територіальні одиниць та вимір організації й функціонування житлово-комунального господарства, виявити їх основні особливості з метою встановлення можливих відмінностей від інших просторових утворень та механізмів управління сферою ЖКГ.

Виклад основного матеріалу дослідження. Сільські території $€$ важливим об'єктом державного регулювання для країни, де переважає агарний тип виробництва, як це відбувається в Україні. Тому сталий розвиток саме таких територій є достатньо гострим питанням в умовах розвитку ринкової економіки та реформування публічної влади 3 передачею більшості функцій держави на рівень місцевого самоврядування. Водночас, сталий розвиток неможливий без масштабної модернізації інфраструктури таких населених пунктів, а особливо його важливої складової - житловокомунального господарства.

Серед наукових шкіл, що займаються дослідженням сільських територій, відбувся розподіл функцій за їх спеціалізацією на вивченні певних аспектів зазначеного процесу. Так, сферою інтересів науки державного управління $€$ дослідження різних аспектів управлінської діяльності органів виконавчої влади та органів місцевого самоврядування, визначення відповідних механізмів, принципів, функцій та технологій. У полі зору представників аграрної економічної науки перебуває аналіз соціально-економічних процесів, які відбуваються на об'єктному рівні. Прерогативою економістів-аграрників $є$ також розроблення концептуальних засад аграрної політики як певного засобу управління аграрним сектором економіки, накреслення стратегічних напрямів розвитку різних сфер АПК. Саме тому за рівнем наробок економістів складається враження про загальний стан наукових досліджень. 
Труднощі у відстеженні історичної еволюції поняття «сільські території» пов'язані з тим, що воно було запроваджено в наукову літературу не так давно, оскільки раніше найчастіше застосовувалися поняття «село» та «сільська місцевість». Водночас введення в науковий обіг було спричинено тому, що ці поняття не $€$ тотожними. Водночас вони висвітлюють різні аспекти одно й того просторового середовища. Також нарівні $з$ цими поняттями використовуються наступні: «аграрний сектор», «аграрний сектор економіки», «сільські поселення», «сільські населені пункти», «сільське господарство», «агровиробництво», «агропродовольчий сектор», «сільськогосподарське виробництво», «сільська економіка», «сільський сектор», «агропромисловий комплекс» тощо. Ці поняття дуже часто використовуються не за своїм прямим значенням і тому відбувається певна плутанина в теорії публічного управління та економіки з управління сільськими територіями.

Тому в нашому дослідженні варто детальніше розглянути поняття «сільський» та «аграрний»; «території» і «поселення». Відповідно до словникових джерел «аграрний» походить від лат. Agrarius, що означає земельний, пов'язано із землею та усім, що стосується володіння землею. Як зазначає В. Ключевський, термін «сільський» ототожнюється зі словом «село», що безпосередньо позначає рілля і поселення, яке розташовано навколо [5, с. 202]. Таким чином, сама назва вказувала на рід діяльності населення таких поселень, його різницю від міського населення. Пізніше за цим словом закріпилося поняття усієї діяльності та окремої галузі занять 3 сільськогосподарського виробництва. Таким чином, сам термін «сільський» мав спочатку галузевий характер, а вже потім його зміст розширився і стосувався здійснення різних функцій таких поселень.

Поняття «сільський» і «аграрний» дуже часто використовують як синонімічні, але за своїми ознаками та історичним контекстом термін «сільський» є ширшим, ніж «аграрний», оскільки останнє містить зміст виробничих, управлінських, споживацьких відносин та відносин власності. Такі відносини значно ширші, ніж просто виробництво агропродукції або агровиробництва. Але в сукупності 
це дуже близько пов'язані терміни. Земля використовується також для промислового та житлового будівництва, пов'язана з реалізацією екологічних функції та збереження природного середовища.

Для визначення сутності сільських територій важливо спиратися на методологічні принципи раціональної територіальної організації суспільства. В. Юрчишин, І. Баланюк ідентифікують територіальну організацію як поєднання функціонуючих структур розселення населення, виробництва, природокористування, які об'єднанні суб'єктами управління 3 метою відтворення життєдіяльності суспільства [17, с. 7-8].

За останні роки було зроблено певні кроки на шляху подолання спрощеного розуміння сутності сільських територій. Це було досягнуто в результаті відходу від галузевого підходу до дослідження сільських територіальних утворень, синтезу різних дослідницьких методів, посилення міждисциплінарних зв'язків, використання наукових доробок різних наукових шкіл та напрямів.

У нових історичних умовах виникла потреба у здійсненні системного реформування українського суспільства, одночасному проведенні адміністративної, аграрної та інших реформ. Це в свою чергу посилило увагу до територіального розвитку суспільства, що також позначилося на рівні наукових досліджень.

Один 3 відомих фахівців із історичної регіоналістики, Я. Верменич, визначаючи поняття «територія» в контексті понять «менеджмент» та «середовище» відзначила, що їх об’єднувальною ланкою виступає людина, яка використовуючи природу, створює умови для власної життєдіяльності в межах певного історичного простору [2, с. 5]. Цей підхід знайшов подальший розвиток у наукових публікаціях. До числа спеціалістів 3 державного управління, в колі зору інтересів яких перебуває територіальний розвиток села, передусім слід віднести В. Мамонову, Н. Нижник, В. Яцубу.

Так, Н. Нижник належить визначення територіального розвитку як режиму функціонування регіональної системи, який орієнтований на позитивну динаміку параметрів рівня і якості життя населення, забезпечення його стійким, збалансованим відтворенням соціального, господарського, ресурсного та 
екологічного потенціалів території [9, с. 39]. Це положення має принципове значення для розуміння сільського розвитку як територіального, а не як галузевого. Достатньо комплексно термін «територія» було розкрито авторським колективом монографії під редакцією В. Яцуби. Поняття території вони визначили «як просторовий базис, сукупність різноманітних ресурсів, середовище взаємодії природи, людини і виробництва» [1, с. 75]. В. Мамонова визначала територію як «відкриту соціально-економічну систему, що має просторове розташування та відносну відокремленість від «зовнішнього середовища» [8, с. 331]. П. Саблук замість категорії «сільські території» використовував термін «сільська місцевість», під якою розумів територію, що перебуває під юрисдикцією сільрад $[15$, c. 200$]$.

Таким чином, сільська територія має фізичний вияв (просторове розміщення), їй притаманна певна флора та фауна, людина 3 іiі потребами та соціальними функціями; це так звана руральна територія, що походить від анг. rural і позначає сільський, яка має просторове розміщення. Вважається, що такі території пов'язані 3 теорією множинної додатковості, коли вони цілком залежать від таких показників як природні умови розміщення, клімат, рельєф, сталість ландшафту, погодні умови тощо. Людина також достатньо сильно впиває на розвиток та стабільність сільських території, але найчастіше це має негативні наслідки для землі, тому і було спричинено увагу до цих питань урядами окремих країн та міжнародною спільнотою у вигляді різноманітних міжнародних організацій.

Сільські території визначаються такими специфічними рисами, як площа та обсяги площі земель, їх протяжність, географічне положення, щільність населення, кліматичні умови, компактність проживання населення, грунти та якість грунтів, особливості ландшафтного середовища. Таким чином, сільські території пов'язані 3 середовищем життєдіяльності в широкому розумінні і це поняття є ширшим, ніж його тлумачення тільки як поселенської території чи адміністративно-територіального виміру.

За рівнем геопросторової організації суспільства сільські території можна розглядати як субтериторіальний складник 
загальнодержавної інтегральної системи розселення. Вона складається 3 таких рівнів ієрархічної системи сільського розселення: низового, районного, міжрайонного, обласного. Їх сукупність утворює сільську підсистему розселення, яка разом із міською утворює загальнодержавну інтегральну систему розселення [10, c. 111].

За місцем сільських поселень в адміністративнотериторіальному устрої України більшістьізних неєадміністративнотериторіальними одиницями. Сільські райони, які мають статус адміністративно-територіальних одиниць, крім хуторів, сіл і селищ об'єднують також селища міського типу (з кількістю населення не менш як 2 тис. осіб) і міста районного значення (з населенням понад 10 тис. осіб).

Області як адміністративно-територіальні одиниці є більш складними за своєю структурою. Поряд із сільськими районами, вони містять «змішаний», перехідний тип поселень - сільські урбанізовані зони та ареали, які утворилися навколо великих міст унаслідок взаємодії урбанізації і руралізації. За територіальним поділом вони належать до сільських адміністративних районів, а функціонально-просторово знаходяться в зоні впливу міст. У чинне правове поле держави не вписуються такі специфічні міські адміністративно-територіальні утворення, на території яких діють кілька самостійних адміністративно-територіальних одиниць, що не створюють єдину територіальну громаду [1, с. 77].

Певні проблеми існують через відсутність чітко визначених і картографічно закріплених меж адміністративно-територіальних одиниць як на рівні областей, адміністративних районів, так i сільських рад. У багатьох випадках на планово-картографічних матеріалах відсутні межі адміністративно-територіальних одиниць, мають місце невинесення їх у натуру або визначення меж таких одиниць без урахування природних, культурно-історичних, демоетнічних особливостей розвитку населених пунктів.

Сільські територіїподіляють відповідно до розмірів та масштабів на декілька рівнів, які побудовані за принципом «матрьошки». Вони розвиваються у часі та просторі, мають взаємозв'язки та 
взаємовпливи між собою та іншими об'єктами управління [11, c. 234].

До низового рівня належать сільські територій, що «знаходяться під юрисдикцією сільської (селищної) ради. У вітчизняній агроекономічній літературі важливою ознакою сільської території вважають наявність на ній сукупності системоутворювальних елементів: соціуму (населення), села (сільського поселення), сільськогосподарських та інших угідь поза межами сільських поселень із розташованими на них виробничими об'єктами» [16, c. $10,11,12]$.

Основним системоутворюючим елементом сільських територій низового рівня є: природне середовище; населення (у споживчому, виробничому, споживчому та управлінському контекстах); власне поселення (як просторове розміщення об'єктів виробництва та життєдіяльності, місце помешкання та постійного перебування населення, що має певні корони та визначені межі); наявний виробничий комплекс та кількість земель сільськогосподарського та несільськогосподарського призначення; соціально-гуманітарна сфера; наявна інфраструктура. Узагальнена характеристика зазначеного рівня сільських територіальних утворень виглядає як середовище виробництва і життєдіяльності сільського населення, локалізоване в певному географічному місці. На низовому рівні сільські території є схожими за структурою, але відрізняються за змістом, територією та розміщенням.

Наступний рівень сільських територій - районний, який структурно об'єднує декілька територій низового рівня, які є частиною певного адміністративного району. Їх організаційним ядром є районний центр у вигляді або селища міського типу, або міста районного чи обласного значення. Як зазначає О. Павлов, «агропромислова інтеграція має виразну тенденцію до спаду, а сільськогосподарське виробництво напівнатуральний характер, можна зробити висновок про випереджальні темпи руралізації цього типу поселень порівняно з процесом урбанізації сіл. За таких умов селища міського типу і міста районного підпорядкування тяжіють до сільських поселень» [7, с. 24]. Водночас він розмежовує цей тип 
поселень за кількісними показниками і вказує, що районний рівень відрізняється також й за якісними показниками, а його властивості й більш різноманітні порівняно із селом, оскільки необхідно зважати, що більша частина населення таких міст або сели міського типу зайнята несільськогосподарською діяльністю. Це призводить до необхідності погодження інтересів територіальних громад сукупних сіл та районного центру, постає проблема у встановленні компетенції та повноважень центрів адміністративного управління, оскільки окрім органів місцевого самоврядування різних рівнів долучаються й органи виконавчої влади. Цей рівень пов〉язаний 3 можливостями для розвитку несільськогосподарських галузей, але для загального розвитку та стабілізації економіки сільських територій.

На рівні області сільські території виступають як просторовофункціональний сегмент певного регіону, який $\epsilon$ складовим елементом макротериторії або території держави, являє собою частину соціального, природного, економічного, інфраструктурного, культурно-історичного i просторового потенціалу країни, яка представлена діяльністю та управлінням національних та місцевих органів влади [7, с. 24]. В ієрархічному вигляді обласний рівень складається із сільських районів, які представляють із себе просторове середовище низових сільських територіальних утворень. Більш складною є структура цих територій на горизонтальному рівні, що обумовлено зростанням кількості сільських територіальних утворень порівняно з районним рівнем, а також через різноманітність галузевої структури, підвищення конкурентності між сільським господарством і промисловістю та іншими галузями виробництва. Важливою є проблема наповнення та розподілу місцевих бюджетів, визначення провідних галузей, вирішення проблемних питань 3 розвитку та аграрного виробництва, з встановлення умов їх відносин з банками та фінансово-кредитними структурами, ведення бізнесу та підприємницького клімату, залучення інвестицій, вирівнювання міжгалузевих дисбалансів та подолання репресивності. Слід сказати, що основні суб' єкти управління територіально знаходяться у містах, що не може не позначатися на розвитку територій цього рівня. Таким чином, сталий розвиток сільських територій 
визначається загальною регіональною політикою i залежить не тільки від місцевої влади, а й районного та обласного рівнів.

Все розмаїття сільських територій обласного рівня формує загальнодержавний рівень. Ця система містить не тільки територіальна утворення низового рівня, а також охоплює підприємства переробних галузей промисловості, інфраструктуру, агросервісні, будівельні, транспортні підприємства, установи i заклади сфери обслуговування, органи державної виконавчої влади та місцевого самоврядування. 3 метою вироблення консенсусу в забезпечення інтересів центрального, районного та муніципального рівнів розробляються та приймаються обласні та загальнодержавні стратегії розвитку. Але «головною функціонально-управлінською проблемою на цьому рівні $є$ подолання галузевого підходу до розвитку сільських територій. Вирішення цієї проблеми полягає у запровадженні політики сільського розвитку, яка є територіальною за визначенням і спрямована на відтворення людського, ресурсного, виробничого, соціального потенціалів сільських територій, покращання життєвого середовища» [12, с. 118].

Слід зазначити, що на сучасному етапі сільські території продовжують займати достатньо велику площу нашої країн, що видно на рис.1.

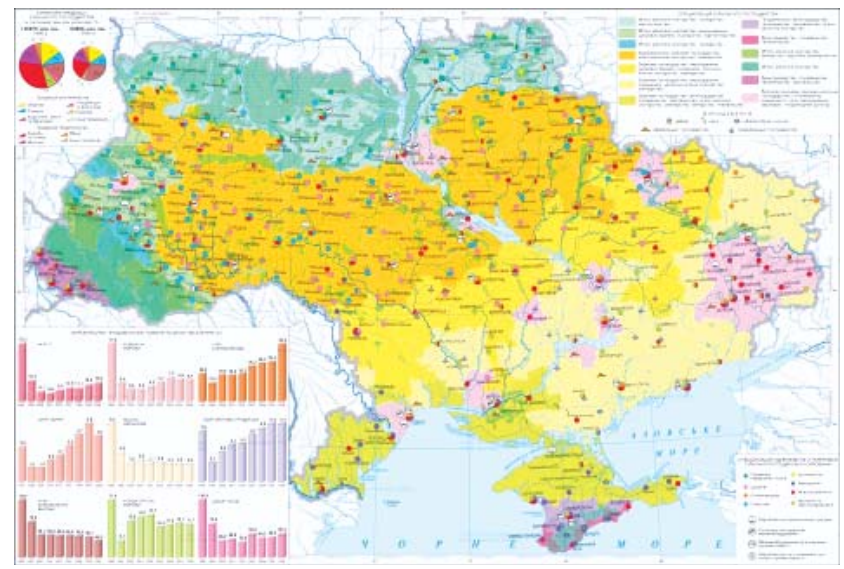

Puc.1 Сільські території на карті України 
Розмежування за типами сільських територій у відповідності до наведених критеріїв не $\epsilon$ чимось остаточним та усталеним. Серед вказаних типів та підтипів доцільно акцентувати увагу на таких, що диференціюються «за видом і режимом використання території, за видами ресурсів та їх забезпеченістю, галузевою спрямованістю, оскільки саме вони відіграють вирішальну роль у відтворювальних процесах. Своєю нетрадиційністю характеризуються території 3 позааграрною спрямованістю розвитку, а також урбаруральні ареали і зони. Вони засвідчують тенденцію посилення зв'язку сільської та міської підсистем суспільства в різних вимірах. Деякі ознаки територій $є$ дихотомічними за визначенням. Так менш руральні території водночас визначаються вищим ступенем урбанізації. Хоча остання $є$ складним і багатофакторним процесом, на який впливають специфіка ресурсного потенціалу, система розселення, планування території, щільність та людність поселень, відстань до міських населених пунктів, розгалуженість та розвиток засобів зв'язку, транспортної мережі тощо» [13, с. 267].

Наразі дуже гостро постає проблема щодо реформування територіального устрою України і тому особливої ваги набуває диференціація сільських територіальних утворень у відповідності до наявності у них статусу адміністративно-територіальних одиниць. Тому було запропоновано для підвищення політико-правового статусу сільських населених пунктів провести їх укрупнення. Але досвід такого проведення висвітлив ряд проблем, однією 3 яких, наприклад, стала проблема штучного їх об’єднання, невирішеність питання зайнятості населення та ін.

Сільські території як об'єкт управління складаються 3 підсистем різної функціональної спрямованості та галузевої підпорядкованості, що позначається на різновекторному характері ïx розвитку. Унаслідок цього в системі утворюється велика кількість комунікативних зв'язків, які породжують складні відносини між компонентами об'єкта, що функціонує, тобто між органами місцевого самоврядування та виконавчої влади різних управлінських рівнів. Їх урахування $є$ необхідною умовою розроблення стратегії розвитку сільських територіальних утворень. 
Сільські території виступають одночасно об’єктом реформи, політики та управління, призначення яких - сприяти відтворенню цього сегменту простору. У тому випадку, коли об'єктом впливу на вказаний об'єкт виступає держава, йдеться саме про державну реформу, державну політику й державне управління. Таке уточнення не $\epsilon$ зайвим, оскільки чинниками реформаторських перетворень, політичних рішень та управлінських дій виступають, окрім вищих органів державної влади, також центральні та місцеві органи виконавчої влади, органи місцевого самоврядування, громадські організації, бізнесові структури, інші суб'єкти політичного процесу. Проте ключові рішення щодо стратегії розвитку сільських територій ухвалюють та контролюють вищі ешелони державної влади, що відображається в механізмах формування та реалізації державної політики.

Процес реформування сільських територіальних утворень виступає як система цілеспрямованих заходів, підпорядкованих меті їх системного перетворення та облаштування як соціальноприродного середовища в інтересах сталого та збалансованого розвитку України. Поки що вийти на такий рівень реформування сільських територій не вдається в силу різних причин та обставин, однією з яких є переважання галузевого підходу в розумінні сутності цих просторових утворень, оцінка процесів, що відбуваються в них iз позиції економічного детермінізму при недооцінці соціального та природного факторів. Більше того, ті зміни, які відбуваються в процесі реформування аграрного сектора економіки, мають переважно спонтанний характер і не є послідовними 3 причини відсутності наукового обгрунтування аграрної політики, адекватної сучасному етапу суспільного розвитку.

Певні рівні сільських територій виступають складовими частинами регіону в його макро-, мезо- та мікровимірах, тому вони підпадають під дію регіональної політики і відповідного управлінського впливу. Регіональну політику слід розглядати як відповідну проекцію політики держави щодо забезпечення сталого та збалансованого соціально-економічного розвитку країни. Ї̈̈ можна визначити як діяльність держави, спрямовану на оптимізацію 
регіональної структури держави та відносин між центром i територіями 3 метою забезпечення динамічного розвитку за рахунок ефективного використання місцевих ресурсів. У контексті територіальної організації суспільства регіональну політику слід розглядати як заходи центральних та регіональних органів державної влади 3 облаштування простору свого існування. Виходячи 3 цих міркувань, необхідно виокремити аспект регіональної політики, спрямований на подолання диспропорцій соціально-економічного розвитку сільських територіальних підсистем суспільства.

Проте ситуація, яка характеризує зазначену галузь, не дає можливості вирішити умі проблемні питання. Серед основних причин негативних явищ визначені такі:

- програми реформування економіки сільського господарства не завжди відповідають результатам їх виконання та визначеним соціальним пріоритетам;

- наявність об'єктивної нерівності в умовах відтворення сільськогосподарського виробництва у порівнянні з іншими видами галузевого виробництва, що пояснюється сезонністю, залежністю від природно-кліматичних умов, довготривалістю виробничих циклів і повільним обігом капіталу та нервування цих факторів при формуванні бюджетної політики на місцевому рівні;

- не зовсім відповідне нормативно-правове забезпечення та захист прав власності сільських мешканців на землю та майно;
- неналежний
рівень
фінансової
підтримки

сільськогосподарського виробництва та соціального розвитку сільських населених пунктів;

- недостатне стимулювання впровадження інноваційних технологій та інвестицій в агропромислове виробництво;

- неврегульованість економічних взаємовідносин між аграрним сектором та іншими галузями виробництва та економіки;

- недостатній рівень державної підтримки облаштування сільських територій;

- неналежне фінансування об'єктів соціальної сфери сільськогосподарських підприємств та їх примусова передача до комунальної власності; 
- слабкі умови для підвищення зайнятості та самозайнятості, створення додаткових робочих місць, збільшення рівнів доходів домогосподарств;

- недостатній рівень розвиткуінфраструктуриаграрногоринку, тінізація та монополізація каналів реалізації сільськогосподарської продукції;

- недостатньо ефективна політика для розвитку кооперативних та інших форм приватної власності для сільськогосподарського виробництва (заготівля, переробка, реалізація продукції, належне фінансове та транспортне обслуговування товарних потоків);

- слабкість інформаційно-комунікаційної політики $з$ питань розвитку в ринкових умовах для сільського населення та правової допомоги [3].

Тому основною метою державної політики повинно бути забезпечення сталого розвитку сільських територій, створення умов для розвитку сільського господарства та посилення його конкурентоспроможності на внутрішньому і зовнішньому ринках, забезпечення продовольчої безпеки країни та надання державних гарантій в цій сфері, розвиток соціально-гуманітарної сфери та культурного дозвілля мешканців сільських територій як носіїв української ідентичності, традицій та духовності.

Слід також враховувати, що сільські території виступають, 3 одного боку, об'єктом адміністративної реформи, 3 іншого впливають на зміст останньої, оскільки їі сутність згідно 3 Концепцією реформування місцевого самоврядування та територіальної організації влади в Україні полягає у формуванні системи державного управління, яка стане близькою до потреб і запитів людей. Головним завданням реформи є утворення сучасної системи місцевого самоврядування, запровадження нової ідеології функціонування виконавчої влади і місцевого самоврядування щодо забезпечення реалізації прав і свобод громадян, надання державних та громадських послуг [6].

Уцьомусенсіважливанестількиконстатаціяцихзміндля розвитку сільських територіальних утворень, скільки використання ситуації, що склалася, для розроблення концептуальних засад реформування 
системи управління та адміністративно-територіального устрою України, які б враховували загальнодержавні, регіональні і місцеві інтереси та потреби сільських територіальних громад.

Враховуючи загальний рух України в напряму формування громадянського суспільства, процес адміністративного реформування слід пов'язувати не тільки 3 розмежуванням повноважень між центральними і місцевими органами виконавчої влади, а й з підвищенням ролі органів місцевого самоврядування.

Зміна відносин власності на землю потребувала здійснення господарської реформи, призначенням якої $\epsilon$ утворення нових організаційно-правових форм господарювання (господарських структур) на базі різноукладності, які визначають економічний устрій сільських територій. Суть цієї реформи полягає у формуванні разом із колективними, сімейними, державними господарствами, приватних сільськогосподарських підприємств. Цей процес набув сталих форм після 2015 року, коли розпочалося інтенсивне перетворення на господарства ринкового типу. При проведенні господарської реформи основну увагу було зосереджено на реформуванні майнових відносин, приватизації майна радгоспів, оренді майна.

Влада та політичні еліта нашої країни демонструє політичну волю щодо проведення земельної реформи та унормування земельних питань, приведення політики розвитку земельних відносин до світових стандартів. Останній етап земельної реформи має на меті ведення земель сільськогосподарського призначення в економічний обіг та використання їх економічного потенціалу для розвитку сільських територій та країни в цілому, визначення на законодавчому рівні та встановлення прозорих засад та правил гри на ринку землі в Україні. Реформа покликана сприяти вирішенню важливих питань з правових, економічних, соціальних та екологічних проблем. Але основними каменями є питання недопущення обезземелення селян, запобігання недобросовісним та шахрайським схемам в галузі продажу земель, визначення регулювання концентрації земель у приватній власності та врегулювання умов оренди земель, недопущення монополізації 
агрохолдінгів, створення умов для нормальних конкурентних відносин, а також підприємницького середовища для середніх та малих підприємств.

У відповідно до Закону України від 7 липня 2011 року «Про державний земельний кадастр» було розпочато земельну реформу в нашій країні і запроваджено сучасну автоматизовану систему кадастру з метою визначення та інвентаризації усіх земель, щоб надалі мати механізми державного забезпечення прав власності та землекористування, оптимізацію землеустрою, поліпшення контролю за використанням та охороною земель, визначення оптимальних та адекватних розмірів плати за землю [4].

Врегулювання ринку землі на законодавчому рівні повинно забезпечити прозорі та відкриті засади фінансових операцій в цій сфері, рівні податків, які можуть бути направлені до місцевого бюджету та розвиток, а також сприяти охороні земель державної та комунальної форм власності, затвердити схеми землеустрою, проведення аукціонів та конкурсів та інших операцій 3 метою забезпечення продажу та оренди землі. В цілому етап земельної реформи поєднані з реформуванням публічного управління та децентралізації і розвитком місцевого самоврядування, посилення його реальної здатності розпоряджатися власними земельними ресурсами, що є одним 3 головних ресурсів для територіальних громад. Також в цьому законі було встановлено прогресивну шкалу державного мита щодо перепродажу земельних ділянок в залежності від терміну їх знаходження у власності продавця.

Сучасне земельне законодавство спрямовано на вирішення питань унормування ринкових умов для здійснення земельних відносин, передбачення важелів для економічного та соціального розвитку села, для чого було передбачено такий механізм як реєстрація суб'єктів господарювання в органах місцевого самоврядування, на територіях яких знаходяться привабливі для оренди землі та території, що має дозволити збільшувати обсяги місцевих бюджетів територіальних громад.

Здемократизацієюсуспільногожиття, розвиткомсамоврядування управлінські відносини будуть ще більше ускладнюватися, набувати 
нової якості та непередбачених наслідків за рахунок збільшення суб'єктів управління, послаблення ролі органів державної влади в управлінні суспільними процесами. 3 іншого боку, прискорений розвиток глобалізації урізноманітнює функції соціальних систем та їх структурних компонентів, тим самим ускладнюючи внутрішньосистемні та міжсистемні відносини.

Територіальний тип управління органічно поєднує управління ресурсами, галузями, функціями, поселенською мережею, ландшафтом, власне територією на іï різних рівнях. Оскільки об'єкт управління перебуває на стадії системного реформування, це передбачає активізацію творчої діяльності органів державної влади. У той же час важко передбачити наслідки управлінського впливу на тій підставі, що процес відтворення переживають і самі суб'єкти суспільних змін.

Крім органів державної влади, в управлінні сільськими територіями беруть участь бізнесові структури, громадські організації, що, 3 одного боку, підвищує конкурентність менеджерської діяльності, а з іншого - потребує іiі координації. Це викликає необхідність розроблення стратегії розвитку сільських територій та здійснення оперативного управління, за рахунок чого 3'являється можливість поєднання інтересів суб'єктів управління різної підпорядкованості. Координатором територіального управління виступає держава, іï органи управління різного рівня та компетенції [14, с.351].

Територіальне управління значно підвищує активну роль у системі управлінських відносин об'єкта управління, який проектує певні управлінські функції суб'єктів, адекватні цілям розвитку, задає певні межі їх дії. Таку визначеність межі, масштабів, глибини й сили впливу суб'єктів на об'єкт завдяки врахуванню природи та функціональності об'єкта ми називаємо суб'єктивізацією об'єкта. У цьому сенсі компетенція та повноваження суб'єктів управління не $\epsilon$ довільними, а залежать від функціонального призначення об'єкта. Це означає, що не тільки при здійсненні управлінської діяльності, а й при виробленні управлінської державної політики слід ураховувати принцип суб'єктивізації об'єкта [14, с.351]. До- 
тримання цього принципу управління сприятиме гармонізації управлінських відносин.

Множина функцій сільських територій як просторового утворення впливає й на субординацію та координацію дій суб'єктів територіального управління, які належать до різних відомств та рівнів. Одночасно в межах цих територій діють суб’єкти управління, не підпорядковані один одному, тобто відбувається накладання i перехрещення вертикального та горизонтального рівнів управління. Обсяг їх повноважень, сфера компетенції визначено чинним законодавством, а розподіл управлінських функцій здійснюється за принципом субсидіарності [14, с.352].

На низовий рівень зазначеного об'єкта поширюється сфера компетенції сільських територіальних громад та їх органів, органів самоорганізації населення, зареєстрованих за місцем їх находження. Цей рівень є найбільш складним в управлінні. В ідеалі на низовому рівні проблема суб'єктивізації об'єкта не повинна стояти як така, оскільки тут об’єкт та суб’єкт управління є неподільними. Але при цьому слід ураховувати рівень розвитку самоврядування на селі. За відсутності фінансових ресурсів територіальна громада неспроможна впоратися з безліччю проблем, які існують у різних сферах життєдіяльності сільського соціуму. 3 огляду на це принцип суб’єктивізації на зазначеному рівні об'єкта виглядає дещо спотвореним, а об'єктно-суб'єктні відносини - асиметричними 3 причини постійного втручання в діяльність територіальних громад органів виконавчої влади та органів місцевого самоврядування різних рівнів.

Висновки. Таким чином, вивчення джерельної бази дослідження щодо управління сільськими територіями дозволило виділити три основні підходи: галузевий, міжгалузевий та територіальний. Наукові підходи щодо аналізу стану об’єкта дослідження еволюціонували у напрямі від галузевого до територіального. Але впровадження територіального підходу само по собі не є свідченням недоцільності використання галузевого підходу. Також було вивчено терміни «аграрний» i «сільський» i встановлено, що на основі різноманітних ознак та історичного розвитку поняття «сільський 
сектор» є значно ширшим, ніж «аграрний сектор». Сільські території визначають як природне, виробниче, антропне середовище, або середовище життєдіяльності в широкому розумінні, тому таке тлумачення є ширшим відносно понять поселенської території або адміністративно-територіальної одиниці.

В розвитку сільських територій виділяють три рівні: низовий, районний, обласний. До низового рівня належать сільські територій, що знаходяться під юрисдикцією сільської (селищної) ради. Наступним рівнем сільських територій $є$ районний. На обласному рівні сільські території визначаються як просторово-функціональна частина регіону, який являє собою складову частину території державиіє певною частиною соціального, природного, економічного, інфраструктурного, культурно-історичного i просторового середовища та потенціалу держави, ця територія знаходиться під управлінням місцевих органів виконавчої влади, органів місцевого самоврядування. Цей розподіл виявляє свою актуальність 3 точки зору розподілу бюджету, має на меті вирішувати суперечки та конфліктні питання між виробниками агропродовольчої продукції, спірні питання з банками та фінансовими установами, сприяти доланню міжгалузевих дисбалансів та репресивності територій. Усе це залежить від координації в системі органів виконавчої влади та місцевого самоврядування та територіальних громад. Суб'єкти управління переважно розміщалися у містах, що також певним чином позначалося на розвитку цих територій, але з проведенням децентралізації та розвитком територіальних громад ці питання були частково вирішені, але в цілому розвиток сільських територій цілком залежить від національної та регіональної політики.

Останнім часом у зв’язку 3 постановкою питання про реформування територіального устрою країни особливого значення набуває диференціація сільських територіальних утворень на такі, що мають, і такі, що не мають статусу адміністративнотериторіальних одиниць. 3 метою підвищення політико-правового статусу сільських населених пунктів пропонується їх укрупнення.

Сільські території як об'єкт управління складаються 3 підсистем різної функціональної спрямованості та галузевої 
підпорядкованості, що позначається на різновекторному характері їх розвитку. Унаслідок цього в системі утворюється велика кількість комунікативних зв'язків, які породжують складні відносини між компонентами об' єкта, що функціонує, тобто між органами місцевого самоврядування та виконавчої влади різних управлінських рівнів.

\section{Стаття надійшла до редакції: 04.10.20}

\section{RURAL AREAS AS AN OBJECT OF PUBLIC POLICY IN THE FIELD OF HOUSING AND COMMUNAL FARMING}

Dmytro Bizonych, Candidate of technical sciences, Director of «Etalontechservice» LLC, Kharkiv, Ukraine.

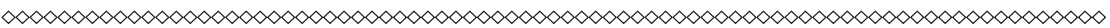

The article deals with the basic concepts of typification of rural areas, which are the territorial basis for the organization of local self-government in our country and management of housing, which in turn is a subsystem of the infrastructure of administrative-territorial units of this level. Problems in the management of rural areas, their differences, which serve as a basis for typification, affect the management of infrastructure facilities, including housing and communal services. The article also identifies the main legal framework for regulating the development of rural areas, further areas for improving public policy in this area. Relationships between rural development and regional development have been established. Housing and communal infrastructure is a component of the infrastructure of the settlement and covers the territorial structure. The units of territorial organization of government and public administration are the country, region, oblast, city, rural administrative district, settlement, ie speaking about the sphere of housing and communal services management, the basic level for its organization and function city.

In the sectoral and territorial aspects, maintaining the necessary proportions of the development of housing and communal services is one 
of the areas of regional development and decentralization, as this area is very problematic in terms of market relations. As for rural settlements (villages and settlements), such territories in public administration occupy a very important place in the context of development and reform of the system of local self-government. They serve as the main resource for securing local self-government in our country and are considered from various state-building aspects.

Currently, the problem of reforming the territorial structure of Ukraine is very acute and therefore the differentiation of rural territorial entities in accordance with the status of administrative-territorial units is of particular importance. Therefore, it was proposed to increase their political and legal status of rural settlements to consolidate them. But the experience of such a holding highlighted a number of problems, one of which, for example, was the problem of their artificial integration, the unresolved issue of employment.

The process of reforming rural territorial formations acts as a system of purposeful measures, subordinated to the goals of their systemic transformation and arrangement as a social and natural environment in the interests of sustainable and balanced development of Ukraine. So far, it is not possible to reach this level of rural reform due to various reasons and circumstances, one of which is the predominance of the sectoral approach in understanding the essence of these spatial formations, assessing the processes occurring in them from the standpoint of economic determinism and underestimating social and natural factors.

Key words: public policy, housing and communal services, government regulation, village, town, rural development, spatial planning, municipal economy.

\section{Received: 04.10.20}




\section{References}

1. Yacuba, V.G. (Ed.). (2003). Administrativno-teritorialnij ustrij Ukraini. Problemni pitannya ta mozhlivi shlyahi ih virishennya [Administrative and territorial structure of Ukraine. Problematic issues and possible ways to solve them]. Kyiv: Poligraf. centr Ukr. DAGP Minekoresursiv Ukrainy [in Ukrainian].

2. Vermenich, Ya.V. (2001). Istorichna regionalistika v Ukrainy [Historical regionalism in Ukraine]. Ukr. ist. zhurn. - Ukrainian Historical Journal, 6, 3-26. [in Ukrainian].

3. Derzhavna cilova programa rozvitku ukrainskogo sela na period do 2015 roku (Postanova KMU, vid 19 veresnya 2007 roku No1158) [State programs for the development of the Ukrainian countryside for the period up to 2015: approved by the Resolution of the Cabinet of Ministers of September 19, 2007 No1158]. zakon2.rada.gov.ua. Retrieved from: http://zakon2.rada.gov.ua/ laws/show/1158-2007-p [in Ukrainian].

4. Zakon Ukrainy Pro derzhavnij zemelnij kadastr, vid 7 lipnya 2011 roku No3613-VI [Law of Ukraine About State Land Cadastre, July 7, 2011 No3613VI]. zakon.rada.gov.ua. Retrieved from: http://zakon.rada.gov.ua/go/3613-17 [in Ukrainian].

5. Klyuchevskij, V.O. (1989). Specialnye kursy [Special courses]. Sochynenyya-Essays, (Vols.4) [in Russian].

6. Koncepciya reformuvannya miscevogo samovryaduvannya ta teritorialnoy organizacii vladi v Ukrainy: Rozporyadzhennya KMU vid 1 kvitnya 2014 roku No333-r [The concept of reforming local self-government and territorial organization of power in Ukraine: Order of the Cabinet of Ministers of April 1, 2014 No333-r]. zakon.rada.gov.ua. Retrieved from: https:// zakon.rada.gov.ua/laws/show/333-2014-\%D1\%80\#Text [in Ukrainian]

7. Leksin, V.N., \& Shvecov, A.N. (1997). Gosudarstvo i regiony. Teoriya $i$ praktika gosudarstvennogo regulirovaniya territorialnogo razvitiya [State and regions. Theory and practice of state regulation of territorial development] [in Russian].

8. Mamonova, V.V. (2005). Upravlinnya teritorialnim rozvitkom na regionalnomu rivni: zmist, spivvidnoshennya [Territorial development management at the regional level: content, ratio]. Aktualni problemi derzhavnogo upravlinnya: Zb. nauk. pr. Hark. reg. in-tu derzh. upr. - Current problems of public administration: Coll. Science. Hark reg. Inst. Of public adm., 2(4), 1., 329-336 [in Ukrainian]. 
9. Nizhnik, N.R. (1998). Derzhavne regulyuvannya teritorialnogo rozvitku [State regulation of territorial development]. Vdoskonalennya sistemi derzhavnogo upravlinnya socialno-ekonomichnimi ta politichnimi procesami $v$ regioni (na prikladi pivdnya Ukraini): Zb. nauk. pr. UADU. - Improving the system of public administration of socio-economic and political processes in the region (on the example of the south of Ukraine): Coll. Science. Paper, UADU, 38-42 [in Ukrainian]

10. Pavlov, O. (2005). Silski poselennya yak elementi integralnoi sistemi rozselennya ta teritorialnogo ustroyu Ukraini [Rural settlements as elements of the integrated settlement system and territorial organization of Ukraine]. Osvita i upravlinnya - Education and management, 2, 110-114 [in Ukrainian].

11. Pavlov, O. (2006). Rivni i tipi silskih teritoriy ta ih sistemna upravlinska model [Levels and types of rural areas and their systemic management model]. Zb. nauk. pr. NADU / Za zag. red. V.I.Lugovogo, V.M.Knyazeva - Coll. Science. Paper NAPA. Vid-vo NADU, 1, 233-243 [in Ukrainian].

12. Pavlov, O.I. (2011). Riznovidi silskih teritorij ta ihni funkcionalni modeli [Varieties of rural areas and their functional models]. Ekonomika APK. Economics of agro-industrial complex, 10 (203), 116-123 [in Ukrainian].

13. Pavlov, O. (2005). Tipizaciya silskih teritoriy za rivnem ih urbanizovanosti [Typification of rural areas according to the level of their urbanization].Visn. NADU. - Bulletin NAPA, 2, 265-270 [in Ukrainian].

14. Pozhe, ZH.-L. (2006). 25 rokiv decentralizacii u Francii: shcho e korisnogo dlya Ukraini [25 years of decentralization in France: what is benefit for Ukraine]. Problemi decentralizacii: nacionalniy ta mizhnarodniy dosvid. Problems of decentralization: national and international experience, K., Atika, 350 - 358 [in Ukrainian].

15. Sabluk, P.T. (Eds). (2000). Reformuvannya socialnoy sferi sela: organizaciyno-metodichni zasadi [Reforming the social sphere of the village: organizational and methodological principles] [in Ukrainian].

16. Socialno-ekonomichni problemi rozvitku ukrainskogo sela i silskih teritoriy: Materiali do Syom. rich. zboriv Vseukr. kongr. vchenih ekonomistivagrarnikiv, 9-10 listop. $2005 \mathrm{r}$. [Socio-economic problems of development of the Ukrainian village and rural areas: Materials to the Seven. meeting All-Ukrainian. congr. agricultural economists, November 9-10. 2005] [in Ukrainian].

17. Yurchishin, V.V., \& Balanyuk, I.F. (1997). Problemi rozvitku agrarnih vidnosin [Problems of development of agrarian relations]. Ekonomika APK. Economics of agro-industrial complex, 7 (33), 3-9 [in Ukrainian]. 


\section{Відомості про авторів / Information about the Author}

Бізонич Дмитро Володимирович: ТОВ «Еталонтехсервіс» м. Харків, Україна.

Dmytro Bizonych: «Etalontechservice» LLC, Kharkiv, Ukraine.

ORCID. ORG./ 0000-0002-0155-7615

E-mail: bizonychdv@ukr.net 